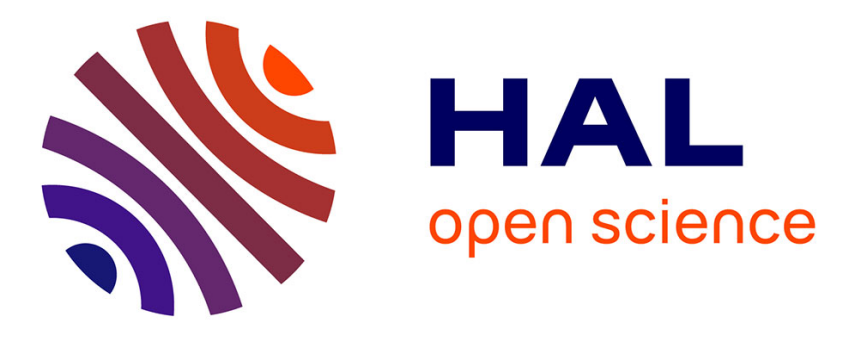

\title{
Novel arsenic hyper-resistant bacteria from an extreme environment, Crven Dol mine, Allchar, North Macedonia
}

Vladimir Bermanec, Tina Paradžik, Snježana Kazazić, Chantelle Venter, Jasna Hrenović, Dušica Vujaklija, Robert Duran, Ivan Boev, Blažo Boev

\section{To cite this version:}

Vladimir Bermanec, Tina Paradžik, Snježana Kazazić, Chantelle Venter, Jasna Hrenović, et al.. Novel arsenic hyper-resistant bacteria from an extreme environment, Crven Dol mine, Allchar, North Macedonia. Journal of Hazardous Materials, 2021, 402, pp.123437. 10.1016/j.jhazmat.2020.123437 . hal02920366

\section{HAL Id: hal-02920366 https://hal.science/hal-02920366}

Submitted on 27 Aug 2020

HAL is a multi-disciplinary open access archive for the deposit and dissemination of scientific research documents, whether they are published or not. The documents may come from teaching and research institutions in France or abroad, or from public or private research centers.
L'archive ouverte pluridisciplinaire HAL, est destinée au dépôt et à la diffusion de documents scientifiques de niveau recherche, publiés ou non, émanant des établissements d'enseignement et de recherche français ou étrangers, des laboratoires publics ou privés. 
Novel arsenic hyper-resistant bacteria from an extreme environment, Crven Dol mine,

\section{Allchar, North Macedonia}

Vladimir Bermanec ${ }^{1} \dagger$, Tina Paradžik ${ }^{2} \dagger$, Snježana P. Kazazić ${ }^{2}$, Chantelle Venter ${ }^{3}$, Jasna Hrenović $^{1 *}$, Dušica Vujaklija ${ }^{2 *}$, Robert Duran ${ }^{4}$, Ivan Boev $^{5}$, Blažo Boev ${ }^{5}$

${ }^{1}$ University of Zagreb, Faculty of Science, Zagreb, Croatia

(vladimir.bermanec@public.carnet.hr, jasna.hrenovic@biol.pmf.hr)

${ }^{2}$ Ruđer Bošković Institute, Bijenička 54, 10000 Zagreb, Croatia

(Dusica.Vujaklija@irb.hr; Tina.Paradzik@irb.hr; Snjezana.Kazazic@irb.hr)

${ }^{3}$ Stellenbosch University, Department of Physiological Sciences, Faculty of Science, Stellenbosch, South Africa (chantellev@sun.ac.za)

${ }^{4}$ Université de Pau et des Pays de 1'Adour/E2S UPPA, IPREM UMR CNRS 5254, Pau, France (rober.duran@univ-pau.fr)

${ }^{5}$ Goce Delčev University of Štip, Štip, North Macedonia (blazo.boev@ugd.edu.mk; ivan.boev@ugd.edu.mk)

$\dagger$ Both authors contributed equally to this manuscript

* Corresponding authors: +3851 4571258 (DV); +3851 6189700 (JH) 


\section{Graphical abstract}

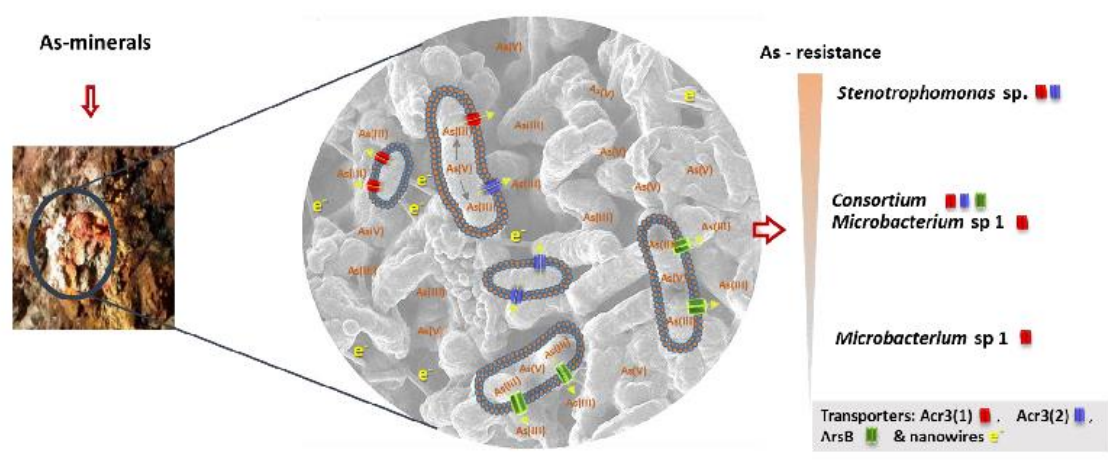

\section{Highlights:}

- As-rich mixture of pharmacolite, hornesite, and talmessite from Crven Dol mine

- Stenotrophomonas sp., Microbacterium spp. and bacterial consortium were isolated

- Novel hyper-resistant bacteria survive $32 \mathrm{~g} / \mathrm{L}$ arsenite and $176 \mathrm{~g} / \mathrm{L}$ arsenate

- As-tolerance involve efflux systems including ArsB, Acr3(1) and Acr3(2) proteins

- SEM/EDS analyses confirmed intracellular accumulation of arsenic

\section{Abstract}

Novel hyper-resistant bacteria were isolated from the Crven Dol mine (Allchar, North Macedonia), arsenic-rich extreme environment. Bacteria were recovered from a secondary mineral mixture, an alteration of hydrothermal realgar rich in arsenates (pharmacolite, hornesite, and talmessite). The sample was recovered from the dark part of the mine at $28 \mathrm{~m}$ depth. Three bacterial strains and a bacterial consortium were isolated for their capacity to survive exposure to $32 \mathrm{~g} / \mathrm{L}(209 \mathrm{mM})$ of arsenite, and $176 \mathrm{~g} / \mathrm{L}(564 \mathrm{mM})$ of arsenate. The $16 \mathrm{~S}$ rRNA gene analysis identified bacterial isolates as Stenotrophomonas sp. and two Microbacterium spp. This analysis also revealed that bacterial consortium comprise two Bacteriodetes exhibiting similarity to Olivibacter ginsengisoli and to uncultured bacterium, 
and one $\gamma$-proteobacteria with similarity to Luteimonas sp. Among all isolates

Stenotrophomonas sp. exhibited the highest tolerance to As compound as well as the capacity to accumulate As inside the cells. Analysis of genes involved in As-resistance showed that recovered isolates possess the genes encoding the ArsB, Acr3(1) and Acr3(2) proteins, indicating that at least a part of their resistance could be ascribed to As-efflux systems described in isolates obtained from human-polluted environments.

Keywords: biogeochemistry, arsenate, arsenite, hyper As-resistance, As-transporters, 16S rRNA

\section{Introduction}

Arsenic has been recognized as one of the most toxic chemical which represent a major public health concern (Hughes et al., 2011). This study focused on the isolation and identification of bacterial community present in the Crven Dol mine, a unique ore body extremely As rich environment, located in Allchar, North Macedonia. The complex geological characteristic of the ore body has been described previously (Palinkas et al., 2018). The most significant mineralization processes occur close to the entrance of adit 21 at the level $-823 \mathrm{~m}$ on the eastern side and close to the vertical shaft (Fig. 1A). Crven Dol minerals are composed of carbonate rocks (dolomite and minor limestone/marble) intruded by a subvolcanic magmatic body highly hydrothermally altered. The chemical composition and rocks were reported in previous studies (Frantz et al., 1994; Janković, 1997). Secondary minerals found in the Crven Dol are weathering products developed through oxidation processes of primary ore minerals, realgar and other sulphides in deposit and its reaction with carbonate mother rock - dolomite. After mining activity in Crven Dol massive realgar body was additionally exposed to 
oxidizing atmosphere and realgar was weathered to mixture of secondary arsenate minerals pharmacolite, hornesite and picropharmacolite (Boev, 2002).

Microorganisms living in such As-rich environments are well adapted to elevated concentrations of As and other toxic compounds (Bruneel et al., 2008; Giloteaux et al., 2010; Volant et al., 2014). As-transforming bacteria, both aerobes and anaerobes, are phylogenetically and physiologically diverse (Suhadolnik et al., 2017). Among them the highly As-resistant bacterial species such as Thiomonas sp., Acidithiobacillus ferrooxidans, Herminiimonas arsenicoxydans, Leptothrix sp. and Stenotrophomonas sp. are well known (Ben Fekih et al., 2018; Ghosh et al., 2018). Many studies revealed that microorganisms have evolved a variety of strategies to survive toxic effects of As compounds. Namely, As typically exists in one of the four oxidation states: $\mathrm{As}(\mathrm{V}), \mathrm{As}(\mathrm{III}), \mathrm{As}(-\mathrm{III})$, and $\mathrm{As}(0)$, among which the most dominant forms are arsenite - As(III), and arsenate - As(V) (Oremland and Stolz, 2003). Trivalent As is generally more toxic than pentavalent As since it binds strongly to vicinal sulfhydryl groups in proteins (Hughes et al., 2011). In contrast, arsenate has the ability to compete with phosphate oxyanions for transport and energetics functions, but its primary toxic effects is due to its transformation to arsenite (Ben Fekih et al., 2018). The widespread resistance mechanisms include the reduction of $\mathrm{As}(\mathrm{V})$ into $\mathrm{As}(\mathrm{III})$ and the efflux of the later from the cell (Fahy et al., 2015). Arsenite transporters are reported for Proteobacteria, Firmicutes and Actinobacteria, while the presence of putative As-resistance genes are confirmed in many sequenced genomes (Fahy et al., 2015). These bacterial efflux systems include members of the two protein families, ArsB and Acr3 which has two subsets designated Acr3(1) and Acr3(2) (Achour et al., 2007). Although these transporters share same function, they exhibit different mechanisms and metalloid specificity (Yang et al., 2015). ArsB proteins are found only in prokaryotes, whereas Acr3 proteins are widespread in bacteria, archaea, fungi and some plants (Castillo and Saier, 2010; Yang et al., 2015). In 
bacteria, the genes encoding for these proteins are found on chromosome, plasmids and transposons, suggesting important role of horizontal gene transfer in bacterial adaptation to As-rich environments. Multiple copies of As-resistant genes contribute to a higher level of resistance to As compound (Ben Fekih et al., 2018).

Since Crven Dol mine is extremely rich in $\mathrm{As}, \mathrm{Sb}, \mathrm{Hg}$ and $\mathrm{Tl}$ representing very hostile environment we expected biological activity to be limited only to microorganisms well adapted to elevated concentrations of As and other toxic compounds. Observed white mineral powder deposited on the rock (Fig. 1B) as a mixture of secondary mineral suggested a possible mineral transformation due to microbial metabolic activity. Taking this into account, the objective of this study was: (i) a mineralogical and geochemical characterization of this secondary minerals rich in As, (ii) isolation and identification of microorganisms which can survive in such harsh environment and (iii) investigation of the As-related genes in order to gain a better insight into the resistance mechanism involved.

\section{Experimental}

\subsection{Site description, sampling, and characterization of a rock sample}

Sample of secondary mineral - a wet white mineral mixture powder, was collected before collapse of Crven Dol mine in 2016 at approximately 28 m depth (GPS coordinates of the entrance are $x-4557$ 750, y - 7580 350, Fig. 1A). Sample was aseptically placed in a sterile plastic tube, and transferred to the laboratory within $24 \mathrm{~h}$. The $\mathrm{pH}$ of sample was determined after its dilution (1:2.5) in distilled water. The mineral composition of sample was determined applying Philips X'Pert diffractometer equipped with spinner using $40 \mathrm{~mA}$ current and $45 \mathrm{kV}$. Anode material was $\mathrm{Cu}$. Start position was $4.01^{\circ} 2 \Theta$, end position $64.99^{\circ} 2 \Theta$ with step size $0.02^{\circ} 2 \Theta$ and scan time $0.5 \mathrm{~s}$. 


\subsection{Isolation and phenotypic characterization of As-resistant bacteria}

One gram of a wet white mineral mixture powder was suspended in peptone water (Biolife, Italy) up to $10 \mathrm{~mL}$. The original and diluted suspensions (up to $\left.10^{-2}\right)$ were directly plated $(0.1$ $\mathrm{mL}$ ) on nonselective nutrient agar (Biolife, Italy). Plates were incubated aerobically at $22{ }^{\circ} \mathrm{C}$ and colony appearances were inspected daily during seven days. Based on the colony size, surface, color and slime-layer production, different morphological variants were selected for further analyses. Selected isolates were Gram-stained and characterized by routine bacteriological techniques. Bacterial growth was tested at various temperatures and fermentation ability was checked on Kligler iron agar (Biolife, Italy). Note that all isolates were maintained on the nutrient agar supplemented with As-compounds to prevent loss of Asresistance in case that resistance genes are associated with mobile genetic elements.

\subsection{MALDI-TOF MS analysis}

Matrix-assisted laser desorption ionization-time of flight mass spectrometry - MALDI-TOF MS (Microflex LT mass spectrometer and software MALDI Biotyper 3.0, Bruker Daltonics, Germany) and MALDI Biotyper database were used for isolate identifications or to further differentiate between closely related species. Species were identified according to the manufacturer's score classification. Procedure based on the direct transfer-formic acid method identification was applied as follows. Small amount of isolate biomass was smeared onto a 96-spot MALDI steel target plate and $1 \mu \mathrm{L}$ of $70 \%$ formic acid (Fisher Chemical, Spain) was added. After drying each spot was overlaid with $1 \mu \mathrm{L}$ of MALDI matrix (saturated solution of $\alpha$-cyano-4-hydroxycinnamic acid ( $\alpha$-HCCA) in 50\% acetonitrile and $2.5 \%$ trifluoroacetic acid), dried and submitted for Biotyper analysis. 


\subsection{Bacterial genomic DNA extraction}

Isolates and bacterial consortium obtained in this study were cultured in peptone water for five days at $22{ }^{\circ} \mathrm{C}$ for genomic DNA extraction. DNA was extracted from the obtained biomass using Wizard Genomic DNA Purification Kit (Promega Corporation, USA), following the recommendations of the manufacturer. The extracted genomic DNA samples were stored at $-20^{\circ} \mathrm{C}$ until further processing.

\subsection{PCR amplification, TA cloning and sequencing}

PCR amplification of 16S rRNA gene for all bacterial isolates were performed using 63F (5'-CAGGCCTAACACATGCAAGTC-3') and 1387 R (5'-GGGCGGWGTGTACAAGGC-3') primers, and cycling conditions as described previously (Giloteaux et al., 2010). In addition, degenerate primers for genes involved in bacterial As detoxification (Fahy et al., 2015), i.e. for arsenite transporters, $\operatorname{arsB}$ (AarsB1F /AarsB1R), and for two subclasses of gene acr3 (acr3(1) - Aacr1F/Aacr2R, and $\operatorname{acr} 3(2)$ - dacr5F/dacr4R) as well as primers targeting arsenite oxidase gene aioA (aoxBM1-2F/ aoxBM3-2R) were used to investigate the presence of targeted genes in the genome of the isolates and consortium. PCR conditions applied for each set of primers were described earlier (Fahy et al., 2015). In order to determine the composition of the bacterial consortium, 16S rRNA PCR products of expected size were cloned using a pGEM®-T Easy Vector Systems (Promega Corporation, USA) and PCR were performed on recombinant colonies. All PCR amplicons were evaluated using agarose gel electrophoresis and gel slices containing PCR products ( 1300 bp 16S rRNA gene, 750 bp of $\operatorname{ars} B$ and of $a c r 3$ ) were purified using Qiagen agarose purification kit. Purified DNA sequences were submitted for sequencing to Macrogen service (South Korea). The 16S rRNA 
gene sequences and translated coding sequences of targeted genes were subjected to a BLAST search (Altschul et al., 1997).

\subsection{Phylogenetic analysis}

The evolutionary relationships of all isolates were performed using partial sequence (1260 nt) of 16S rRNA gene. Multiple sequence alignment (MSA) of 16S rRNA gene sequences was performed using Clustal Omega (Sievers et al., 2011). Phylogenetic trees of 16S rRNA gene sequences were constructed using maximum likelihood method in PhyML (Guindon et al., 2010). aLRT values (approximate likelihood ratio test) were used to infer branch support. The branches with aLRT values over 0.9 were considered well supported. FigTree software (http://tree.bio.ed.ac.uk/software/figtree/) was used for statistical report and graphic presentation of the results. The nucleotide sequences of 16S rRNA genes, as well as transporter genes, $\operatorname{ars} B, \operatorname{acr} 3(1)$ and $\operatorname{acr} 3(2)$ were deposited in the NCBI GeneBank under accession number (to be added in proof).

\subsection{Analysis of As-tolerance of bacterial isolates}

The As-tolerance was determined for bacterial consortium and the three pure bacterial cultures. The tested concentration of sodium arsenite $\left(\mathrm{NaAsO}_{2}\right)$ were $0.25-32 \mathrm{~g} / \mathrm{L}$, and for sodium arsenate $\left(\mathrm{Na}_{2} \mathrm{HAsO}_{4} \cdot 7 \mathrm{H}_{2} \mathrm{O}\right) 2.75-176 \mathrm{~g} / \mathrm{L}$ in Luria-Bertani (LB) broth after aerobic incubation for five days at $22^{\circ} \mathrm{C}$ (Sunita et al., 2012). The tolerance of all isolates to As was determined as MTC, maximum tolerable concentration resulting in undisturbed colony formation; as MIC, minimum inhibitory concentration causing the visible inhibition of bacterial growth; and as $\mathrm{MBC}$, minimum bactericidal concentration resulting in lack of colony formation. The MTC, MIC and MBC were determined by inoculation of $10 \mu \mathrm{L}$ from each 
experimental tube on the nutrient agar following the incubation of plates at $22{ }^{\circ} \mathrm{C}$ for five days using as a positive control bacteria grown in LB broth without addition of As salts.

\subsection{Scanning electron microscopy / energy dispersive spectroscopy analyses}

Pure culture of Stenotrophomonas sp. and the Consortium growing at MTC of As-compounds were further examined by scanning electron microscopy / energy dispersive spectroscopy (SEM/EDS) analysis. Glutaraldehyde-fixed bacterial cells were processed according to standard procedures for scanning electron microscopy (SEM). Briefly, the samples were washed in phosphate buffer, dehydrated through a graded series of ethanol, dried in hexamethyldisilizane (HMDS) and transferred onto coverslips. Dry samples were subsequently placed onto aluminium stubs and carbon coated before imaging the samples with the Zeiss Crossbeam 540 FEG SEM using the InLens detector at $0.5 \mathrm{kV}$. The EDS analysis (Oxford Instruments, United Kingdom) was done using 20kV and Backscatter detector on at least three areas on the sample. The As content in cells of Stenotrophomonas sp. and Consortium exposed to arsenite and arsenate was compared. Statistical analyses were carried out using Statistica 13.3 software (TIBCO Software Inc.). For pairwise comparisons ordinary t-test for independent variables was used. Decisions regarding statistical significance were made at $\mathrm{p}<0.05$.

\section{Results and Discussion}

\subsection{Characterization of the white mineral mixture}

The white mineral mixture powder collected in Crven Dol mine (Fig. 1) and suspended in water had $\mathrm{pH}$ 6.9. The X-ray diffraction XRD analysis showed a mixture of gypsum $\left(\mathrm{CaSO} 4 \cdot 2 \mathrm{H}_{2} \mathrm{O}\right)$ and arsenates $\left(\mathrm{AsO}_{4}\right)^{3-}$ including: pharmacolite $\left(\mathrm{CaH}\left(\mathrm{AsO}_{4}\right) \cdot 2 \mathrm{H}_{2} \mathrm{O}\right)$, hornesite 
$\left(\mathrm{Mg}_{3}\left(\mathrm{AsO}_{4}\right)_{2} \cdot 8 \mathrm{H}_{2} \mathrm{O}\right)$, and talmessite $\left(\mathrm{Ca}_{2} \mathrm{Mg}\left(\mathrm{AsO}_{4}\right)_{2} \cdot 2 \mathrm{H}_{2} \mathrm{O}\right)$ which are common in carbonate host rock. These minerals are formed under supergene oxidation after exposition of primary ore minerals (realgar and orpiment) to weathering processes (Boev, 2002). It has been shown that the process of transforming realgar (AsS) to As-rich secondary minerals is accelerated by microbial metabolism resulting in a mixture of arsenate minerals and gypsum (Drewniak and Sklodowska, 2013). Thus, we hypothesized that As-rich white mineral mixture sample (Fig. 1) collected at Crven Dol mine possesses bacterial community highly resistant to As.

\subsection{Isolation and characterization of As-resistant bacteria}

By plating peptone water with suspended rock sample on solid LB medium four clearly distinct colony types were obtained after one week of growth. The colonies varied in size and colour, from translucent to a pale-yellow and yellow. Bigger size colonies, were covered by clear sticky matrix. It is well know that bacterial communities form biofilms embedded in a self-producing matrix, which help them to survive in a hostile environment (Flemming et al., 2016). Extracellular matrix helps bacterial cells attachment to the mineral surface and act as biosorbent of toxic metals in extreme environment (Gupta and Diwan, 2017). Thus, we selected one big colony covered with matrix, one extremely small and translucent colony and two colonies with similar size and differing in colour (Table 1). The bacterial isolates were characterized by Gram-staining and growth capacities at different temperatures (Table 1). Analysed bacterial cultures were able to grow aerobically on nutrient agar at $22{ }^{\circ} \mathrm{C}$ and at 36 ${ }^{\circ} \mathrm{C}$, but none of them were able to grow at $42{ }^{\circ} \mathrm{C}$ (Table 1). This suggested that the recovered isolates were adapted to the temperature conditions $\left(16^{\circ} \mathrm{C}\right)$ in the mine environment.

Further, physiological resistance of isolates (1-4) exposed to elevated concentrations of arsenite and arsenate was examined. All bacterial isolates were able to survive 32g/L (209 
$\mathrm{mM}$ ) of sodium arsenite, and $176 \mathrm{~g} / \mathrm{L}(564 \mathrm{mM})$ of sodium arsenate (Table 2). This level of resistance to arsenate is recognized as hyper-resistance (Drewniak et al., 2008). Such elevated resistance was comparable to As-resistant bacteria isolated from diverse As contaminated environments (Achour et al., 2007; Sunita et al., 2012). Usually bacteria exhibit lower resistance to arsenite with MIC from 1-10 mM (Achour et al., 2007; Drewniak et al., 2008). Only a very few reports described bacteria resistant to arsenite up to $80 \mathrm{mM}$ (Achour et al., 2007; Chen and Shao, 2009; Maizel et al., 2016). In this study, Isolate 2 showed exceptional tolerance to arsenate and arsenite without showing any disturbance in colony formation (Table 2). Its resistance (MTC) particularly to arsenite (209 mM) is 2.6 times higher than 80 $\mathrm{mM}$ so far described for an isolate closely related to Microbacterium esteraromaticum (Chen and Shao, 2009). The metabolic capacities of the isolated strains in this study represent an important asset to colonize As rich environment as previously demonstrated for microorganisms colonizing mine impacted environments (Bruneel et al., 2006; Bertin et al., 2011) and volcano (Medrano-Santillana et al., 2017).

\subsection{Identification and phylogenetic analysis}

The 16S rRNA partial gene amplification (over $1260 \mathrm{nt}$ ), and sequencing revealed that Isolate 1 comprise mixture of various $16 \mathrm{~S}$ rRNA genes indicating that it corresponds to a bacterial consortium. In order to identify the members of this consortium, a 16S rRNA gene library was constructed. The sequencing of 45 clones and BLAST analysis revealed that the consortium comprises three strains. Two of them were affiliated to Bacteriodetes: one bacterium representing $47 \%$ (21 clones) in the consortium shared $98.6 \%$ identity (98\% coverage) with Parapedobacter pyrenivorans strain P-4 and the other bacterium (22\%, 10 clones) shared 95\% identity (94\% coverage) with Olivibacter ginsengisoli strain Gsoil 060 and with uncultured bacterium clone SIBG789_N12D2_16S_B (95.2\% identity and $94 \%$ coverage). 
The third strain was affiliated to $\gamma$-proteobacteria and representing $31 \%$ of bacteria in the consortium (14 clones) shared $99.8 \%$ identity (89\% coverage) with Luteimonas sp. strain BO171. The coverage of this library was $100 \%$ (97\% similarity) as shown by Good's C estimator indicating that sufficient number of clones were analyzed to reveal entire bacterial diversity (Good, 1953). The Isolates 2, 3 and 4 were obtained as pure bacterial cultures. Isolate 2 had $100 \%$ identity (100\% coverage) with Stenothrophomonas maltophilia $(\gamma-$ proteobacteria) while Isolate 3 had 100\% identity (100\% coverage) with Microbacterium murale strain S3A-15, strain 01-Gi-001 and strain M-sp VKM Ac-2016. Isolate 4 shared 99.8\% identity (99\% coverage) with Microbacterium sp. R28 isolated from copper polluted soil and with M. esteraromaticum strains TRB35 and OBE2. The phylogenetic analyses based on the comparison of $16 \mathrm{~S}$ rRNA gene sequences obtained in this study with closely related sequences deposited in database are shown in Fig. 2. The isolates from Crven Dol mine belong to bacterial phyla known for their capacity to survive in As-rich ecosystem (Liu et al., 2018). The phylogenetic tree shows that the two strains (Isolates 3 and 4) belonging to the genus Microbacterium were clearly separated (Fig. 2), suggesting that they correspond to two distinct species explaining their different As-survival capacities (Table 2).

The comprehensive overview of MALDI TOF MS-based microbial characterization at the subspecies and strain levels has been published recently (Demirev and Sandrin, 2016). The discriminating power of this method is derived from the measurement of highly abundant proteins like ribosomal proteins, which makes it almost independent from cultivation conditions. Consistently, we performed MALDI TOF MS analysis and our results showed that Microbacterium isolates identified by $16 \mathrm{~S}$ rRNA approach produced clearly different protein patterns (Fig. 3). The specific protein fingerprints were obtained in mass range from 2 to 12 $\mathrm{kDa}$. Thus, in line with the phylogenetic analysis MALDI-TOF MS also discriminated two 
isolates but at the proteome level. Noteworthy, although Biotyper database contains 37 Microbacterium species (including M. murale) MALDI TOF MS was unable to identify confidently the Isolates 3 and 4 (score was below threshold; <1.7).

MALDI TOF MS was also applied to analyse pure culture of Stenotrophomonas strain (Isolate 2). The score values obtained for Stenotrophomonas sp. varied from 1.702 -1.726. Although this scoring was low, according to the manufacturer it was sufficient to probable identification of isolates to the genus level (from 1.700 to 1.999). Thus, this result was in concert with 16S rRNA gene identification.

\subsection{Functional analysis}

The isolates were also analysed for the presence of the functional genes involved in arsenic transformations, aioA, and $\operatorname{ars} C$, and for genes involved in the As-efflux system, $\operatorname{ars} B$, and acr3(1) and $\operatorname{acr} 3(1)$. Applying the conditions described previously (Fahy et al., 2015) we were not able to detect the presence of the genes encoding arsenite oxidase (aioA, large subunit) or cytoplasmic arsenate reductase $(\operatorname{ar} C)$. Either these bacteria have very divergent genes involved in As transformation, which could explain lacking of the PCR signal with the primers used in this study or other genes contribute to the hyper As-resistance mechanisms. However, PCR amplification and sequencing confirmed the presence of the genes associated with As-efflux system in all isolates (1-4). Gene encoding arsenite efflux pump (arsB) was detected only in bacterial consortium. Amplified nucleotide sequence exhibited $97 \%$ identity (99\% coverage) with $\operatorname{ars} B$ gene encoding As-pump membrane protein from uncultured Lysobacter sp. clone SE1-12* and 95\% identity with Luteimonas sp. YGD11-2. This result was not surprising because both genera belong to the same family Xanthomonadaceae (order Xanthomonadales $\gamma$-proteobacteria). 
The $\operatorname{acr} 3(1)$ and $\operatorname{acr} 3(2)$ genes targeted in this study were detected in all isolates and phylogeny of their corresponding products were presented in Fig. 4. The Acr3(1) detected in Consortium exhibited $96.6 \%$ identity (99\% coverage) with Acr3(1) protein from $S$. maltophilia. This is not surprising since the identical sequence of Acr3(1) protein was found in Stenotrophomonas strain (Isolate 2), the pure culture isolated from the Consortium. We cannot exclude the possibility of the horizontal gene transfer between the members of the same order. Namely, the Stenotrophomonas sp. also belongs to order Xanthomonadales as Luteimonas sp. detected by $16 \mathrm{~S}$ rRNA gene analysis (Fig. 2). Note that the members of this order possess highly conserved Acr3(1) transporters (96.6\% identity according to Blast analysis). The gene products Acr3(1) from Microbacterium species (Isolate 3 and Isolate 4) exhibited highest similarity with Acr 3(1) protein from Microbacterium sp. CH12i (95.8 \% identity and 98\% coverage) and with Acr3(1) family arsenite efflux transporter Microbacterium (identity 100\% and $93 \%$ coverage) respectively. These results further confirmed the diversity of these strains.

The acr3(2) genes encoding Acr3(2) transporters were also detected in this study. In consortium the Acr3(2) was most closely related to Acr3(2) from Luteimonas mephitis (95\% coverage and $95 \%$ identity) and in Stenotrophomonas sp. (Isolate 2) with arsenite efflux transporter from Stenotrophomonas sp. HMWF023 (99\% identity and 96.5\% coverage). Consistently with previous report acr3(2) genes were not detected in Microbacterium strains (Achour et al., 2007).

Overall, the phylogeny based on acr3(1) and (2) genes was congruent with 16S rRNA phylogeny (Figs. 2 and 4). Since all isolates possessed As-resistance genes it is likely that isolates represent primary bacterial colonizer. The hyper As-resistance of all isolates in particular of Stenotrophomonas sp. (Isolate 2) might be the result of increased number of genes involved in efflux system, as previously reported in Burkholderiales which members 
isolated from the As-rich environments have increased number of the As-related genes on their genomes (Li et al., 2014). Since Stenotrophomonas sp. (Isolate 2) showed exceptional arsenite and arsenate resistance we further characterized the metabolic capacity of this strain.

\subsection{Characterization of Stenotrophomonas sp. (Isolate 2)}

\subsubsection{Pigment production}

While cultivating the isolates at $36^{\circ} \mathrm{C}$, we noticed that Stenotrophomonas sp. (Isolate 2) produced water-soluble brown pigment (Fig. 5). Pigment production plays a significant role in protection against various environmental stresses. For example, it was reported that the presence of heavy metal increase the pigmentation of various bacteria (Lima e Silva et al., 2012). Melanin (brown pigment) produced by various bacteria exhibit excellent heavy metal binding capacity and as such has very good potential for application in bioremediation (Thaira et al., 2019). High temperature also trigger pigment production in bacteria. Similarly to our observation, at elevated temperature Pseudomatermonas species SM 9913 produces pyomelanin (brown pigment) with a protective role against heat damage (Zeng et al., 2017). Thus, it is possible that Stenotrophomonas sp, (Isolate 2) by producing the brown pigment at elevated temperature increases its heat resistance and probably tolerance to heavy metal as demonstrated (Thaira et al., 2019). The comparison of MALDI-TOF MS pattern of Stenotrophomonas sp. grown at $36{ }^{\circ} \mathrm{C}$ to that of the bacterium grown at $22{ }^{\circ} \mathrm{C}$ revealed two peptides of approx. 2300 and 2400 Da specifically produced at $36{ }^{\circ} \mathrm{C}$ (Fig. 5). This observation suggested that these proteins might be involved in the bacterial response to exposure at higher temperature together with the production of the soluble brown-pigment. Further proteomic analyses are required to better understand the pigment production at high temperature and its role. 


\subsubsection{Antibiotic resistance}

Stenotrophomonas species range from common soil organisms to opportunistic human pathogens (Hrenovic et al., 2019). The MALDI-TOF MS protein pattern of the Stenotrophomonas sp. isolate was similar to that of Stenotrophomonas maltophilia, which is known to be naturally resistant to a large-spectrum antibiotics (including all carbapenems) via two inducible chromosomal metallo- $\beta$-lactamases (Denton and Kerr, 1998). Consistently, the Stenotrophomonas sp. isolate was able to grow on CHROMagar revealing its carbapenemresistance capacity. Such observation is not surprising since antibiotic resistance, particularly carbapenem-resistance, has been found linked with metal resistance including As (Villa et al., 2013).

\subsubsection{Cell integrity and the As-sorption capacity}

Stenotrophomonas sp. was further examined by SEM/EDS in order to determine the As effect on the cell integrity and the As-sorption capacity. For comparison, the Consortium was also examined as a reference. In the absence of As, Stenotrophomonas sp. and bacterial consortium showed rod-shaped cells connected together with nanowire like structures (Fig. 7). Bacterial nanowires are well known to play a crucial role in transport of electrons when bacteria grow on minerals (Sure et al., 2016). In the presence of arsenite at MTC, we observed the production extracellular matrix (Fig. 7, middle panel). When exposed to arsenate at MTC the elongation of rod cells connected with nanowires was observed for both, Stenotrophomonas sp. and Consortium cells (Fig. 7, right panel). This observation could not clarify the hyper resistance of Stenotrophomonas sp. (Isolate 2) to As compounds.

To get insights on the accumulation of As compounds into the cells, EDS analysis was performed. Isolates were grown at MTC as described in Materials and Methods. Note that 
Consortium was exposed to eight times lower concentration of arsenite and two times lower concentration of arsenate in comparison to Stenotrophomonas sp. As shown in Figure 8, the Stenotrophomonas sp. (Isolate 2) and Consortium (Isolate 1) cells were able to sorb Ascompounds $(0.12-0.34$ dry wt $\%)$. In both isolates, the As content varies depending on the cell exposure to arsenite or arsenate. Significantly higher difference was observed for the Stenotrophomonas sp. ( 3X) in contrast to Consortium cells ( 1.3 X). Comparison of As content between isolates showed that when grown on arsenate the As-content reached its highest value and was very similar in both isolates. This might be explained by the fact that arsenate is less toxic to bacterial cells (Hughes et al., 2011) and was accumulating at the same level in the both isolates (Fig. 8). It can be also seen that Consortium accumulated more arsenic ( 2X) than Stenotrophomonas sp. when exposed to arsenite (Fig. 8). Taking into account the MTC values for Consortium and Isolate 2 our results clearly show that Stenotrophomonas sp. has either better efflux system or transformation mechanisms to remove As-compounds from the cells when exposed to arsenite.

Based on the current knowledge, we propose that the As probably accumulate into the cell as arsenate-As(V), which is less toxic and able to interact with thiol groups present in small molecules such as glutathione (GSH) forming As-complexes retained into the cell. Because the aio $\mathrm{A}$ and $\operatorname{ars} \mathrm{C}$ genes were not detected in the isolates, it is likely that $\mathrm{As}(\mathrm{V})$ entering the cell, probably via phosphate transporters (Garbinski et al., 2019), are retained inside of the cell by thiol-containing molecules while arsenite-As(III) is expulsed through the ACR3 efflux-pumps. It should be also pointed out that only As transporters were identified in the isolated bacteria. Thus, we cannot exclude the possibility that high resistance of bacterial isolates is due to other As-transforming genes, such as As-reductase or oxidase, which were not detected. Clearly, future research and the next generation whole genome sequencing are 
required to gain a deeper understanding of the mechanisms that these microorganisms have evolved to enhance resilience to harsh environmental conditions.

Finally, although arsenic efflux system are found in almost every organisms the molecular mechanisms of arsenic transport and many novel genes that contribute to As resistance remains to be determined (Garbinski et al., 2019). Despite this, microorganisms or plants adapted to respond to environmental challenges can be very promising bioremediation agents. Such as bacteria that we isolated in the Crven Dol mine or plants (Bačeva et al., 2014) with capacity to accumulate heavy metals found in the surrounding environment of Allchar area. Microbial-based remediation is generally considered as a promising technology for the treatment of metal contaminated soils but requires optimal conditions favouring sorption mechanisms while limiting desorption (Jin et al., 2018). Therefore, further studies are needed to found the optimised conditions for using the Isolates obtained in this study in bioremediation processes.

\section{Conclusions}

Bacterial consortium and three novel bacterial species belonging to the genera Stenotrophomonas and Microbacterium were recovered from As-rich mineral mixture collected at the Crven Dol mine, North Macedonia. These bacteria have an important role in the transformation of primary to secondary oxidized mineral. Consortium and bacterial isolates exhibited high resistance to arsenite and arsenate in comparison to reported Asresistant bacteria. Particularly Stenotrophomonas sp. (Isolate 2) exhibited so far undescribed hyper-resistance to arsenite $(209 \mathrm{mM})$ together with extremely high resistance to arsenate $(564 \mathrm{mM})$. These results demonstrate the potential use of this isolate for bioremediation. Extreme environments, such as Crven Dol mine, are promising niches to explore for the 
recovery of bacterial strains having high metal tolerance capacity, which represent an important asset for the bioremediation of metal polluted areas.

CRediT author statement

Vladimir Bermanec -Conceptualization, Validation, Writing - Original Draft

Tina Paradžik- Investigation, Formal analysis, Validation, Writing - Original Draft

Snježana P. Kazazić - Investigation, Resources, Writing - Original Draft, Writing - Review \& Editing

Chantelle Venter - Investigation, Resources, Formal analysis, Writing - Review \& Editing, Jasna Hrenović - Conceptualization, Resources, Investigation, Formal analysis Writing Original Draft

Dušica Vujaklija - Conceptualization, Investigation, Validation, Resources, Writing Original Draft Writing - Review \& Editing

Robert Duran -Validation, Writing - Original Draft, Writing - Review \& Editing

Ivan Boev - Investigation, Formal analysis

Blažo Boev - Investigation, Formal analysis, Writing - Original Draft

Declaration of interests

$\bigotimes$ The authors declare that they have no known competing financial interests or personal relationships that could have appeared to influence the work reported in this paper.

\section{Acknowledgements}


This work has been supported in a part by the Croatian Science Foundation (project no. IP2014-09-5656) and in part by the Centre of Excellence for Bioprospecting of the Adriatic Sea, Ruđer Bošković Institute, Croatia. We also acknowledge the support of the French/Croatian bilateral program PHC-Cogito 2019-20 (to DV and RD). 


\section{References}

Achour, A.R., Bauda, P., and Billard, P. (2007). Diversity of arsenite transporter genes from arsenicresistant soil bacteria. Res Microbiol 158(2), 128-137. doi: 10.1016/j.resmic.2006.11.006.

Altschul, S.F., Madden, T.L., Schaffer, A.A., Zhang, J., Zhang, Z., Miller, W., et al. (1997). Gapped BLAST and PSI-BLAST: a new generation of protein database search programs. Nucleic Acids Res 25(17), 3389-3402. doi: gka562 [pii].

Bačeva, K., Stafilov, T., and Matevski, V. (2014). Bioaccumulation of Heavy Metals by Endemic Viola Species from the Soil in the Vicinity of the As-Sb-Tl Mine "Allchar", Republic of Macedonia. International Journal of Phytoremediation 16(4), 347-365. doi: 10.1080/15226514.2013.783551.

Ben Fekih, I., Zhang, C., Li, Y.P., Zhao, Y., Alwathnani, H.A., Saquib, Q., et al. (2018). Distribution of Arsenic Resistance Genes in Prokaryotes. Front Microbiol 9, 2473. doi: 10.3389/fmicb.2018.02473.

Ben Said, O., Louati, H., Soltani, A., Preud'homme, H., Cravo-Laureau, C., Got, P., et al. (2015). Changes of benthic bacteria and meiofauna assemblages during bio-treatments of anthracenecontaminated sediments from Bizerta lagoon (Tunisia). Environ Sci Pollut Res Int 22(20), 15319-15331. doi: 10.1007/s11356-015-4105-7.

Bertin, P.N., Heinrich-Salmeron, A., Pelletier, E., Goulhen-Chollet, F., Arsene-Ploetze, F., Gallien, S., et al. (2011). Metabolic diversity among main microorganisms inside an arsenic-rich ecosystem revealed by meta- and proteo-genomics. ISME J 5(11), 1735-1747. doi: 10.1038/ismej.2011.51.

Boev, B., Bermanec, V., Serafimovski, T., Lepitkova, S., Mikulčić, S., Šoufek, M., Jovanovski, G., Stafilov, T., Najdoski, M. (2002). Allchar mineral assemblage. Geologica Macedonica 15-16, $1-23$.

Bruneel, O., Duran, R., Casiot, C., Elbaz-Poulichet, F., and Personne, J.C. (2006). Diversity of microorganisms in Fe-As-rich acid mine drainage waters of Carnoules, France. Appl Environ Microbiol 72(1), 551-556. doi: 10.1128/AEM.72.1.551-556.2006.

Bruneel, O., Pascault, N., Egal, M., Bancon-Montigny, C., Goni-Urriza, M.S., Elbaz-Poulichet, F., et al. (2008). Archaeal diversity in a Fe-As rich acid mine drainage at Carnoules (France). Extremophiles 12(4), 563-571. doi: 10.1007/s00792-008-0160-z.

Castillo, R., and Saier, M.H. (2010). Functional Promiscuity of Homologues of the Bacterial ArsA ATPases. Int J Microbiol 2010, 187373. doi: 10.1155/2010/187373.

Chen, S., and Shao, Z. (2009). Isolation and diversity analysis of arsenite-resistant bacteria in communities enriched from deep-sea sediments of the Southwest Indian Ocean Ridge. Extremophiles 13(1), 39-48. doi: 10.1007/s00792-008-0195-1.

Demirev, P., and Sandrin, T.R. (2016). Applications of Mass Spectrometry in Microbiology. Springer, Cham.

Denton, M., and Kerr, K.G. (1998). Microbiological and clinical aspects of infection associated with Stenotrophomonas maltophilia. Clin Microbiol Rev 11(1), 57-80.

Drewniak, L., and Sklodowska, A. (2013). Arsenic-transforming microbes and their role in biomining processes. Environ Sci Pollut Res Int 20(11), 7728-7739. doi: 10.1007/s11356-012-1449-0.

Drewniak, L., Styczek, A., Majder-Lopatka, M., and Sklodowska, A. (2008). Bacteria, hypertolerant to arsenic in the rocks of an ancient gold mine, and their potential role in dissemination of arsenic pollution. Environ Pollut 156(3), 1069-1074. doi: 10.1016/j.envpol.2008.04.019.

Fahy, A., Giloteaux, L., Bertin, P., Le Paslier, D., Medigue, C., Weissenbach, J., et al. (2015). 16S rRNA and As-Related Functional Diversity: Contrasting Fingerprints in Arsenic-Rich Sediments from an Acid Mine Drainage. Microb Ecol 70(1), 154-167. doi: 10.1007/s00248014-0558-3. 
Flemming, H.C., Wingender, J., Szewzyk, U., Steinberg, P., Rice, S.A., and Kjelleberg, S. (2016). Biofilms: an emergent form of bacterial life. Nat Rev Microbiol 14(9), 563-575. doi: 10.1038/nrmicro.2016.94.

Frantz, E., Palme, H., Todt, W., Elgoresy, A., and Pavicevic, M. (1994). Geochemistry of Tl-as Minerals and Host Rocks at Allchar (Fyr Macedonia). Neues Jahrbuch Fur MineralogieAbhandlungen 167(2-3), 359-399.

Garbinski, L.D., Rosen, B.P., and Chen, J. (2019). Pathways of arsenic uptake and efflux. Environ Int 126, 585-597. doi: 10.1016/j.envint.2019.02.058.

Ghosh, D., Bhadury, P., and Routh, J. (2018). Coping with arsenic stress: Adaptations of arseniteoxidizing bacterial membrane lipids to increasing arsenic levels. Microbiologyopen 7(5), e00594. doi: 10.1002/mbo3.594.

Giloteaux, L., Goni-Urriza, M., and Duran, R. (2010). Nested PCR and New Primers for Analysis of Sulfate-Reducing Bacteria in Low-Cell-Biomass Environments. Applied and Environmental Microbiology 76(9), 2856-2865. doi: 10.1128/Aem.02023-09.

Good, I.J. (1953). The Population Frequencies of Species and the Estimation of Population Parameters. Biometrika 40(3/4), 237-264. doi: 10.2307/2333344.

Guindon, S., Dufayard, J.F., Lefort, V., Anisimova, M., Hordijk, W., and Gascuel, O. (2010). New algorithms and methods to estimate maximum-likelihood phylogenies: assessing the performance of PhyML 3.0. Syst Biol 59(3), 307-321. doi: 10.1093/sysbio/syq010.

Gupta, P., and Diwan, B. (2017). Bacterial Exopolysaccharide mediated heavy metal removal: A Review on biosynthesis, mechanism and remediation strategies. Biotechnol Rep (Amst) 13, 5871. doi: 10.1016/j.btre.2016.12.006.

Hrenovic, J., Durn, G., Kazazic, S., Dekic, S., and Music, M.S. (2019). Untreated wastewater as a source of carbapenem-resistant bacteria to the riverine ecosystem. Water $\mathrm{Sa}$ 45(1), 55-62. doi: 10.4314/wsa.v45i1.07.

Hughes, M.F., Beck, B.D., Chen, Y., Lewis, A.S., and Thomas, D.J. (2011). Arsenic exposure and toxicology: a historical perspective. Toxicol Sci 123(2), 305-332. doi: 10.1093/toxsci/kfr184.

Janković, S., Boev, B., Serafimovski, T., (1997). Magmatism and Tertiary Mineralization of the Kozuf Metalogenetic District, the Republic of Macedonia, With Particular Reference to the Allchar Deposit. Skopje: University St. Kiril and Metodij, Faculty of Mining and Geology-Stip.

Jin, Y., Luan, Y., Ning, Y., and Wang, L. (2018). Effects and Mechanisms of Microbial Remediation of Heavy Metals in Soil: A Critical Review. Applied Sciences 8(8), 1336.

Li, X., Zhang, L., and Wang, G. (2014). Genomic evidence reveals the extreme diversity and wide distribution of the arsenic-related genes in Burkholderiales. PLoS One 9(3), e92236. doi: 10.1371/journal.pone.0092236.

Lima e Silva, A.A.d., Carvalho, M.A.R.d., Souza, S.A.L.d., Dias, P.M.T., Silva Filho, R.G.d., Saramago, C.S.d.M., et al. (2012). Heavy metal tolerance (Cr, $\mathrm{Ag}$ and $\mathrm{Hg}$ ) in bacteria isolated from sewage. Brazilian Journal of Microbiology 43, 1620-1631.

Liu, J.L., Yao, J., Wang, F., Ni, W., Liu, X.Y., Sunahara, G., et al. (2018). China's most typical nonferrous organic-metal facilities own specific microbial communities. Sci Rep 8(1), 12570. doi: 10.1038/s41598-018-30519-1.

Maizel, D., Blum, J.S., Ferrero, M.A., Utturkar, S.M., Brown, S.D., Rosen, B.P., et al. (2016). Characterization of the extremely arsenic-resistant Brevibacterium linens strain AE038-8 isolated from contaminated groundwater in Tucuman, Argentina. International Biodeterioration \& Biodegradation 107, 147-153. doi: 10.1016/j.ibiod.2015.11.022.

Medrano-Santillana, M., Souza-Brito, E.M., Duran, R., Gutierrez-Corona, F., and Reyna-Lopez, G.E. (2017). Bacterial diversity in fumarole environments of the Paricutin volcano, Michoacan (Mexico). Extremophiles 21(3), 499-511. doi: 10.1007/s00792-017-0920-8.

Oremland, R.S., and Stolz, J.F. (2003). The ecology of arsenic. Science 300(5621), 939-944. doi: 10.1126/science. 1081903.

Palinkas, S.S., Hofstra, A.H., Percival, T.J., Sostaric, S.B., Palinkas, L., Bermanec, V., et al. (2018). Comparison of the Allchar Au-As-Sb-Tl Deposit, Republic of Macedonia, with Carlin-Type Gold Deposits. Diversity of Carlin-Style Gold Deposits 20, 335-363. doi: 10.5382/rev.20.10. 
Sievers, F., Wilm, A., Dineen, D., Gibson, T.J., Karplus, K., Li, W., et al. (2011). Fast, scalable generation of high-quality protein multiple sequence alignments using Clustal Omega. Mol Syst Biol 7, 539. doi: 10.1038/msb.2011.75.

Suhadolnik, M.L.S., Salgado, A.P.C., Scholte, L.L.S., Bleicher, L., Costa, P.S., Reis, M.P., et al. (2017). Novel arsenic-transforming bacteria and the diversity of their arsenic-related genes and enzymes arising from arsenic-polluted freshwater sediment. Sci Rep 7(1), 11231. doi: 10.1038/s41598-017-11548-8.

Sunita, M.S.L., Prashant, S., Chari, P.V.B., Rao, S.N., Balaravi, P., and Kishor, P.B.K. (2012). Molecular identification of arsenic-resistant estuarine bacteria and characterization of their ars genotype. Ecotoxicology 21(1), 202-212. doi: 10.1007/s10646-011-0779-x.

Sure, S., Ackland, M.L., Gaur, A., Gupta, P., Adholeya, A., and Kochar, M. (2016). Probing Synechocystis-Arsenic Interactions through Extracellular Nanowires. Front Microbiol 7. doi: 10.3389/Fmicb.2016.01134.

Thaira, H., Raval, K., Manirethan, V., and Balakrishnan, R.M. (2019). Melanin nano-pigments for heavy metal remediation from water. Separation Science and Technology 54(2), 265-274. doi: 10.1080/01496395.2018.1443132.

Villa, L., Capone, A., Fortini, D., Dolejska, M., Rodriguez, I., Taglietti, F., et al. (2013). Reversion to susceptibility of a carbapenem-resistant clinical isolate of Klebsiella pneumoniae producing KPC-3. J Antimicrob Chemother 68(11), 2482-2486. doi: 10.1093/jac/dkt235.

Volant, A., Bruneel, O., Desoeuvre, A., Hery, M., Casiot, C., Bru, N., et al. (2014). Diversity and spatiotemporal dynamics of bacterial communities: physicochemical and other drivers along an acid mine drainage. Fems Microbiology Ecology 90(1), 247-263. doi: 10.1111/15746941.12394.

Yang, Y., Wu, S., Lilley, R.M., and Zhang, R. (2015). The diversity of membrane transporters encoded in bacterial arsenic-resistance operons. PeerJ 3, e943. doi: 10.7717/peerj.943.

Zeng, Z., Cai, X., Wang, P., Guo, Y., Liu, X., Li, B., et al. (2017). Biofilm Formation and Heat Stress Induce Pyomelanin Production in Deep-Sea Pseudoalteromonas sp. SM9913. Front Microbiol 8, 1822. doi: 10.3389/fmicb.2017.01822. 


\section{Figure captions}

Fig. 1. A) Sampling position in Crven Dol mine and simplified geological setting of ore body. GPS coordinates of the entrance to the mine are shown. B) Alteration zone around realgar mineralization: the wet white mineral mixture powder (the secondary mineral) was sampled for chemical and microbiological characterization in this study.

Fig. 2. Phylogenetic tree of isolated bacteria based on 16S rRNA gene sequences. aLRT values are shown for main branches.

Fig 3. Comparison of MALDI TOF mass spectra obtained for Microbacterium species, Isolate 3 and Isolate 4. Differences in the protein profile of two species are marked with an asterisks.

Fig. 4. Phylogenetic tree based on the Acr3(1) and (2) As-efflux transporters. aLRT values are shown for main branches.

Fig. 5. Production of water-soluble brown pigment by Stenotrophomonas sp. at $36^{\circ} \mathrm{C}$, but not at $22^{\circ} \mathrm{C}$.

Fig. 6. Comparison of MALDI TOF mass spectra obtained for Stenotrophomonas sp. (Isolate 2) grown at $22^{\circ} \mathrm{C}$ (blue) and $36^{\circ} \mathrm{C}$ (red). Differences in the protein profile are marked with asterisks. 
Fig. 7. Scanning electron micrographs of Stenotrophomonas sp. (Isolate 2) and Consortium. Left panel is showing cells grown in the absence of As salts; middle panel cells grown in the presence of arsenite at MTC; right panel cell grown in the presence of arsenate at MTC. Nanowires are marked with arrows, and possible traces of the extracellular matrix with circles.

Fig. 8. The As content (wt \%) in dry sample of isolate Stenotrophomonas sp. and Consortium determined by EDS analysis. Cells after contact with MTC values of arsenite and arsenate: a) significantly higher than cells exposed to arsenite; b) significantly higher than in cells of Stenotrophomonas sp. exposed to MTC of arsenite. 


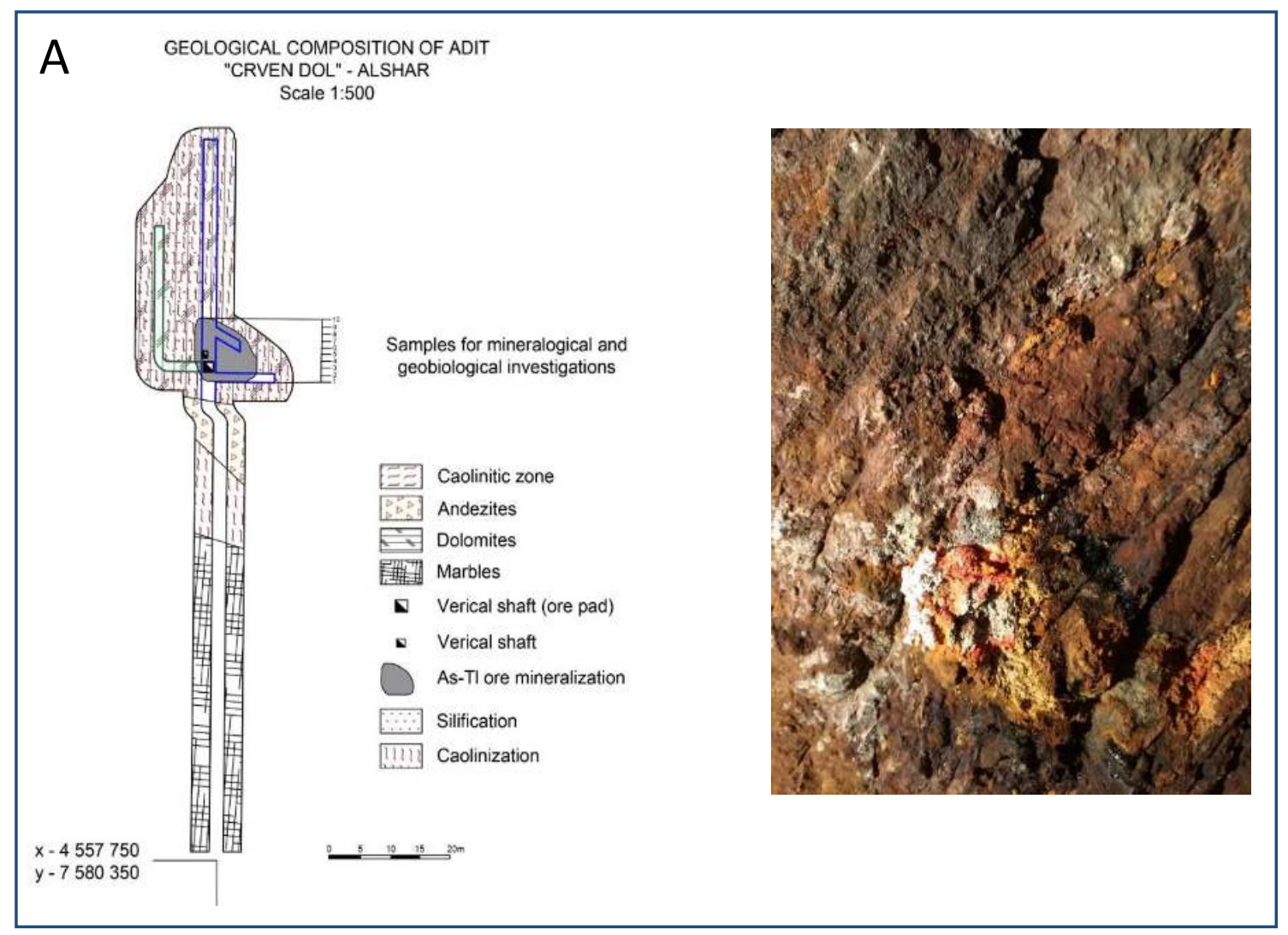

Fig. 1. A) Sampling position in Crven Dol mine and simplified geological setting of ore body. GPS coordinates of the entrance to the mine are shown. B) Alteration zone around realgar mineralization: the wet white mineral mixture powder (the secondary mineral) was sampled for chemical and microbiological characterization in this study. 


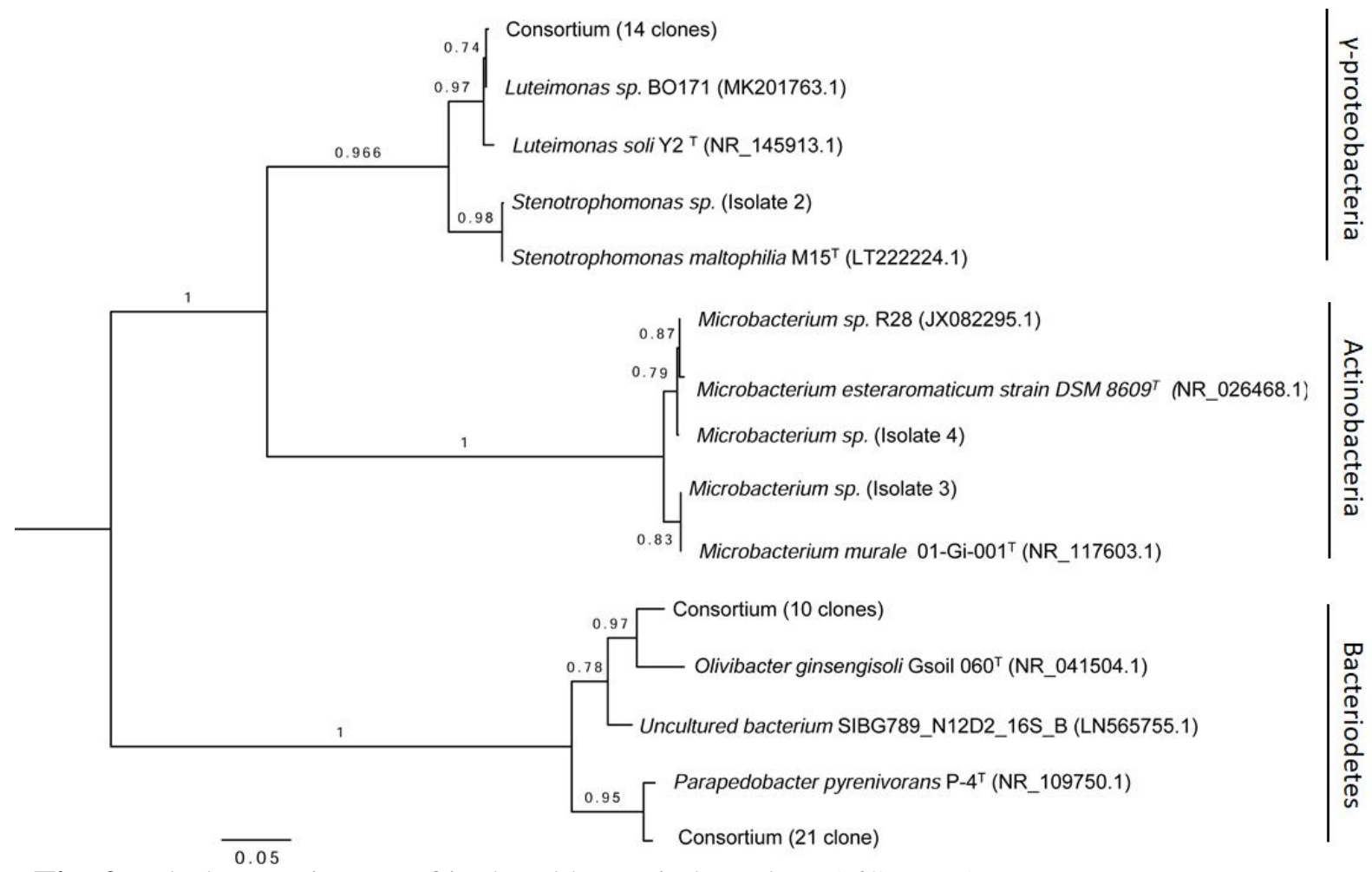

Fig. 2. Phylogenetic tree of isolated bacteria based on $16 \mathrm{~S}$ rRNA gene sequences. aLRT values are shown for main branches.

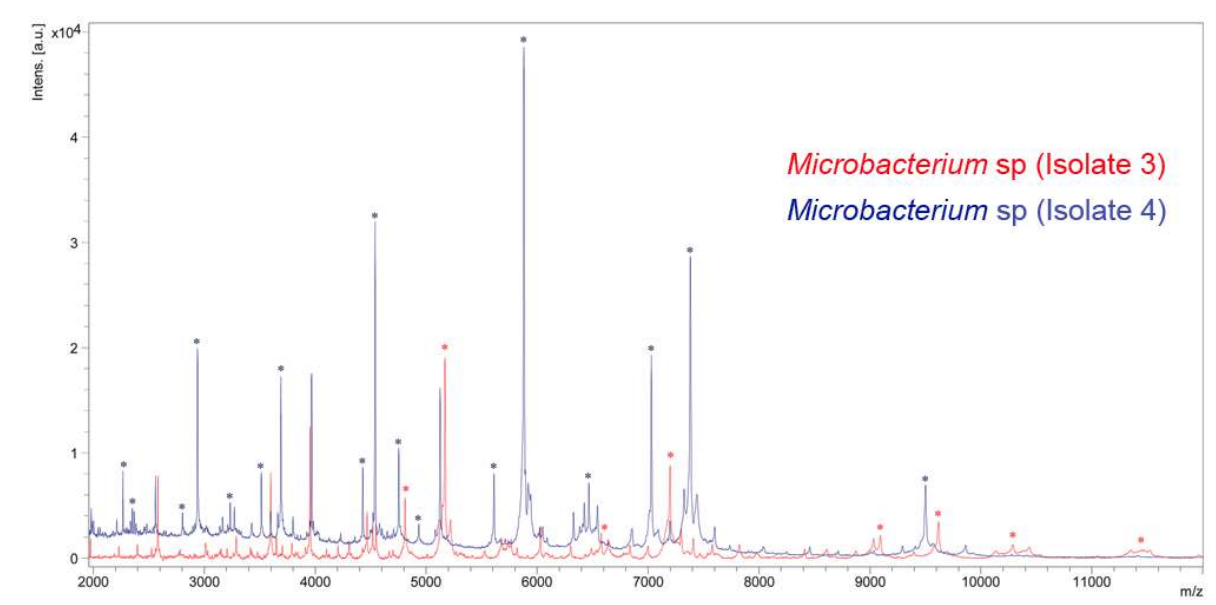

Fig 3. Comparison of MALDI TOF mass spectra obtained for Microbacterium species, Isolate 3 and Isolate 4. Differences in the protein profile of two species are marked with an asterisks. 


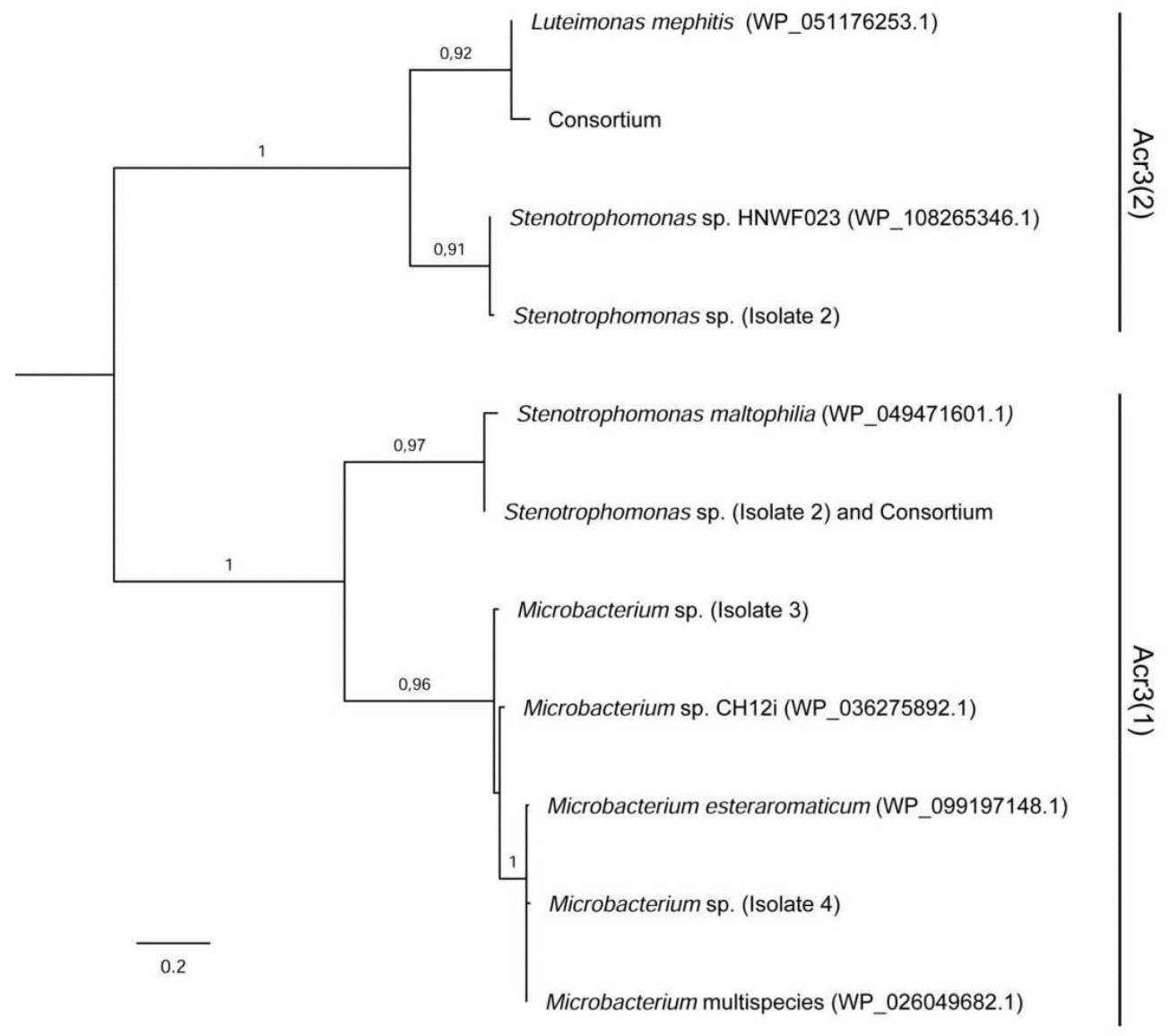

Fig. 4. Phylogenetic tree based on the Acr3(1) and (2) As-efflux transporters. aLRT values are shown for main branches.

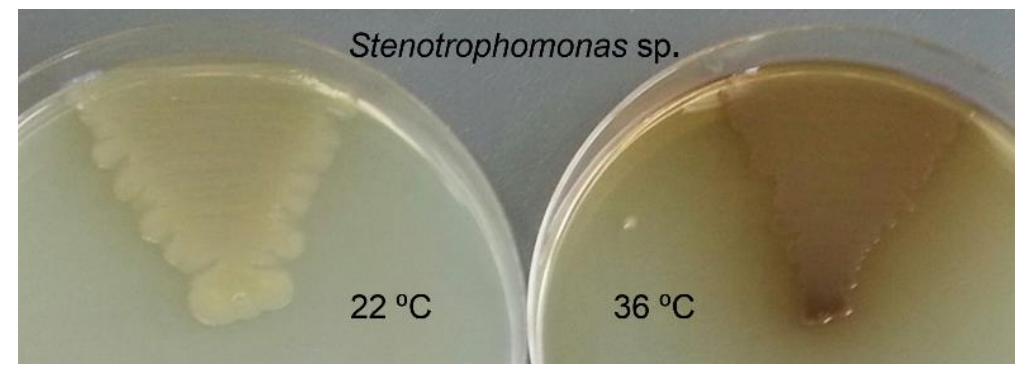

Fig. 5. Production of water-soluble brown pigment by Stenotrophomonas sp. at $36^{\circ} \mathrm{C}$, but not at $22{ }^{\circ} \mathrm{C}$. 


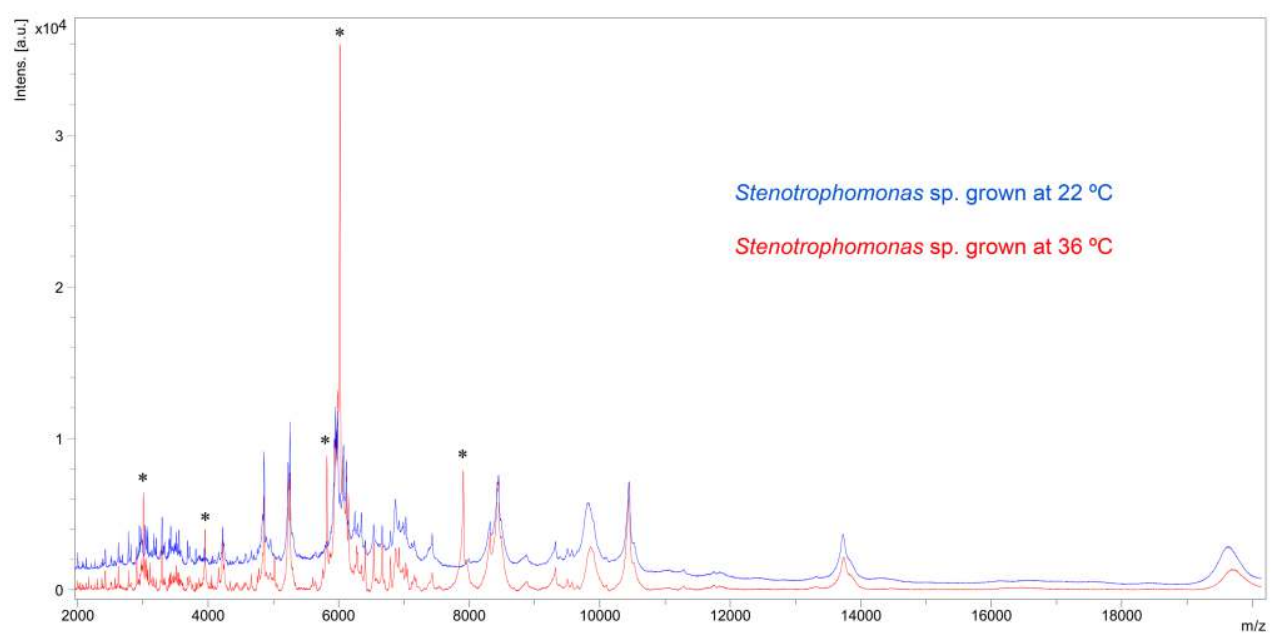

Fig. 6. Comparison of MALDI TOF mass spectra obtained for Stenotrophomonas sp. (Isolate 2) grown at $22{ }^{\circ} \mathrm{C}$ (blue) and $36{ }^{\circ} \mathrm{C}$ (red). Differences in the protein profile are marked with asterisks.
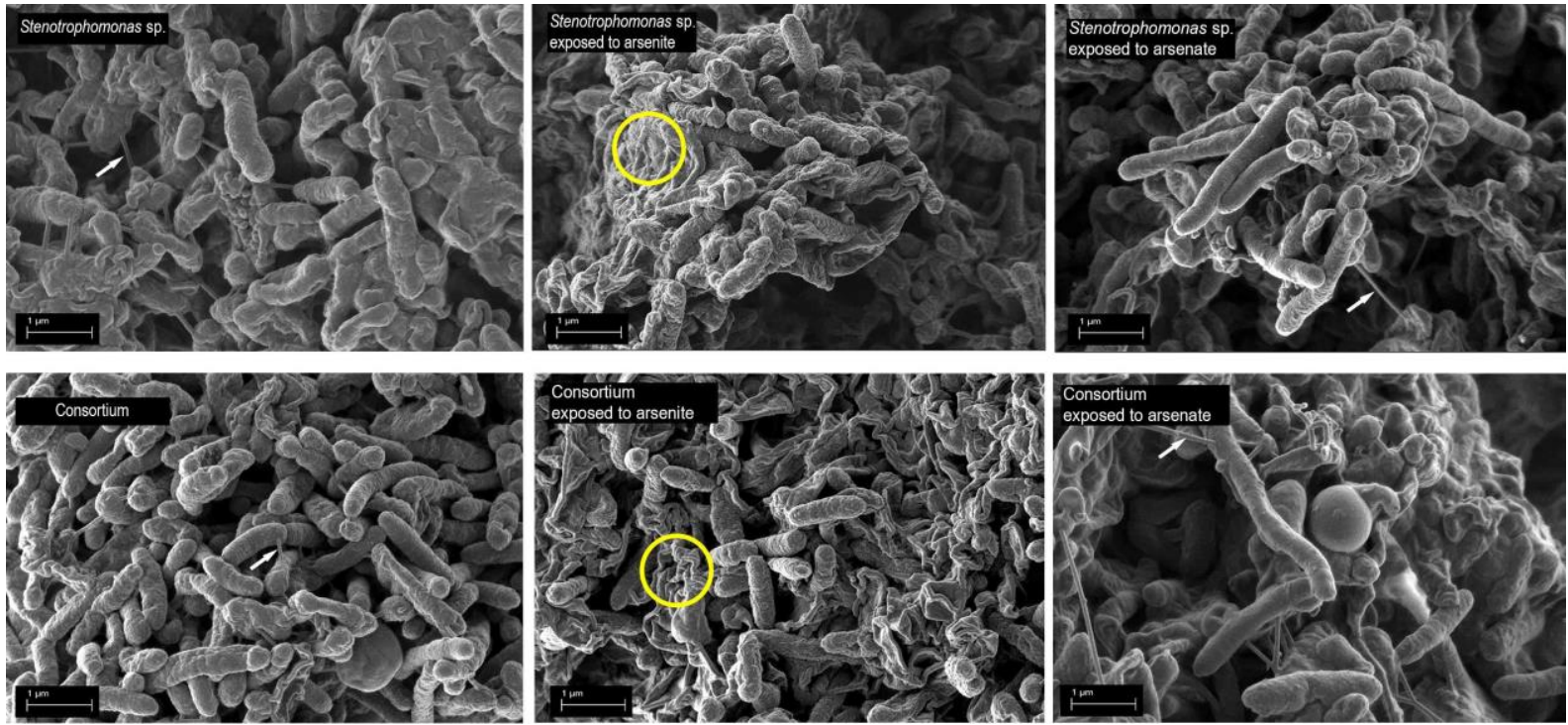

Fig. 7. Scanning electron micrographs of Stenotrophomonas sp. (Isolate 2) and Consortium. Left panel is showing cells grown in the absence of As salts; middle panel cells grown in the presence of arsenite at MTC; right panel cell grown in the presence of arsenate at MTC. Nanowires are marked with arrows, and possible traces of the extracellular matrix with circles. 


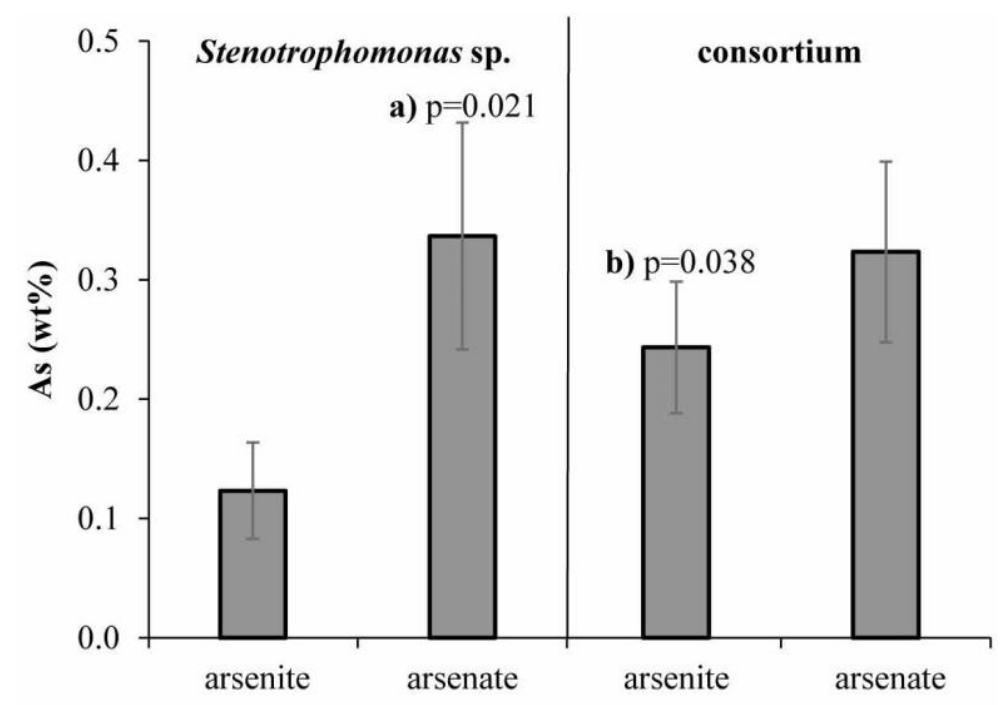

Fig. 8. The As content (wt \%) in dry sample of isolate Stenotrophomonas sp. and Consortium determined by EDS analysis. Cells after contact with MTC values of arsenite and arsenate: a) significantly higher than cells exposed to arsenite; b) significantly higher than in cells of Stenotrophomonas sp. exposed to MTC of arsenite. 
Table 1. General characteristics of isolated colonies. All isolates were non-fermentative roads.

\begin{tabular}{|l|l|l|l|l|}
\hline Colony morphology of Isolates & $\begin{array}{l}\text { Gram } \\
\text { stain }\end{array}$ & $\begin{array}{l}\text { Growth at } \\
22{ }^{\circ} \mathrm{C}\end{array}$ & $\begin{array}{l}\text { Growth at } \\
36{ }^{\circ} \mathrm{C}\end{array}$ & $\begin{array}{l}\text { Growth at } \\
42^{\circ} \mathrm{C}\end{array}$ \\
\hline $\begin{array}{l}\text { 1: } \text { white - pale yellow, big size and } \\
\text { covered by slime }\end{array}$ & $-/+$ & + & + & - \\
\hline 2: pale yellow & - & + & + & - \\
\hline 3: yellow & + & + & + & - \\
\hline 4: translucent, very small in size & + & + & + & - \\
\hline
\end{tabular}

Production of dark brown pigment was observed when Isolate 2 was grown at $36{ }^{\circ} \mathrm{C}$ (Fig. 5).

Table 2. Determination of As-tolerance of bacterial consortium and pure cultures isolated from As-rich mineral mixture.

\begin{tabular}{|l|l|l|l|l|}
\hline As-resistance & Isolate 1 & Isolate 2 & Isolate 3 & Isolate 4 \\
\hline Arsenite & & & & \\
\hline MTC $(\mathrm{g} / \mathrm{L})$ & 4 & $>32$ & 4 & 1 \\
\hline MIC $(\mathrm{g} / \mathrm{L})$ & 8 & $>32$ & 8 & 2 \\
\hline MBC $(\mathrm{g} / \mathrm{L})$ & $>32$ & $>32$ & $>32$ & $>32$ \\
\hline Arsenate & & & & \\
\hline MTC (g/L) & 88 & $>176$ & 88 & 3 \\
\hline MIC (g/L) & 176 & $>176$ & 176 & 6 \\
\hline MBC (g/L) & $>176$ & $>176$ & $>176$ & $>176$ \\
\hline
\end{tabular}

